\title{
FILSAFAT PENDIDIKAN YANG MEMBEBASKAN DALAM PERSPEKTIF PENDIDIKAN ISLAM
}

\author{
Samsul Bahri \\ Universitas Satyagama Jakarta
}

\begin{abstract}
:
This paper examines the liberating philosophy of education in the perspective of Islamic education. The method used is descriptiveanalytical with historical approach. This study found that liberation education philosophy became a mission in the world of Islamic education and has occurred in the time of the Prophet Muhammad until the golden age of Islam. However, after the decline of the Islamic world until now virtually a dichotomous virus has occurred, even liberation education philosophy no longer occurs in the world of Islamic education. Therefore, Islamic education should be able to be a means of liberation to prepare learners to plunge in people's lives. In addition, the dichotomy of science should be abolished by the view that science is all derived from Islam. Liberate education will be realized if Islamic education is willing to reorient: Having a clear vision, mission, and strategic orientation. Strong social, intellectual and moral legitimacy.to the society and respond to the demands of the era Managed with modern management that is professional, rational, open, accountable, humanist, has access, cooperation and global partnership.
\end{abstract}

Keywords: Philosophy of education, leberty, Islam

\section{Abstrak:}

Tulisan ini mengkaji filsafat pendidikan yang membebaskan dalam perspektif pendidikan Islam. Metode yang digunakan deskriftifanalitis dengan pendekatan historis.Studi ini berhasil menemukan bahwa filsafat pendidikan pembebasan menjadi misi dalam dunia pendidikan Islam dan pernah terjadi pada zaman Rasulullah SAW 
sampai pada zaman keemasan Islam. Namun demikian, setelah kemunduran dunia Islam sampai sekarang praktis virus dikotomi telah terjadi, bahkan filsafat pendidikan pembebasan tidak lagi terjadi dalam dunia pendidikan Islam. Oleh karena itu, pendidikan Islam seharusnya mampu menjadi sarana pembebasan untuk menyiapkan peserta didik untuk terjun dalam kehidupan masyarakat. Di samping itu, dikotomi ilmu sudah seharusnya ditiadakan dengan memandang bahwa ilmu itu satu semuanya berasal dari Islam. Pendidikan yang membebaskan akan terwujud jika pendidikan Islam mau melakukan reorientasi:Memiliki visi, misi, dan orientasi strategis ke depan yang jelas. Memiliki legistimasi sosial, intelektual dan moral yang kuat, pada masyarakat dan meresponi tuntutan zaman dikelolah dengan menajemen modern yang profesoinal, rasional, terbuka, akuntabel, humanis, memiliki akses, kerjasama dan kemitraan global.

Kata Kunci: Filsafat pendidikan, pembebasan, Islam.

\section{PENDAHULUAN}

Wacana tentang pendidikan tidak akan pernah sepi dari kritikan-kritikan tajam yang dilontarkan oleh para intelektual, hal ini disebabkan karena model-model pendidikan yang diharap sebagai sebuah sarana memanusiakan manusia dan membebaskannya dari distorsi kemanusiaan yang hakiki tidak lagi terjadi, justru sebaliknya pendidikan tidak lagi membebaskan manusia atau peserta didik, serta seluruh komponen pendidikan. Kenyataan tersebut, menyebabkan lahirnya pemikiran tentang wacana pembubaran lembaga sekolah, Ivan Illic misalnya mengatakan bahwa lembaga-lembaga sekolah yang sudah ada ini harus digusur alias dibubarkan semua. Menurutnya, sekolah bukanlah lembaga pendidikan akan tetapi lembaga penindasan rakyat kecil, lembaga yang melestarikan feodalisme, lembaga yang 
melanggengkan kolonialisme, lembaga yang menjujung tinggi status quo, bahkan lembaga yang mengabdikan sistem persaingan model hukum rimba. Atau memakai istilah Ainurrafiq "Emoh Sekolah " karena sekolah dianggap sebagai biang keladi munculnya dikotomisasi antara pendidikan dan pengajaran atau penyekolahan. ${ }^{1}$ Wacana di atas, merupakan bentuk dari kritik kepada dunia pendidikan yang tidak lagi mempunyai filsafat pendidikan yang membebaskan peserta didik dan seluruh komponen pendidikan. Hal ini akan menjadi sangat relevan manakala kita menyadari kondisi dan praktek pendidikan di Indonesia, oleh karena itu, pemikiran tersebut merupakan wujud dari kegelisahan seseorang yang masih punya hati nurani kemanusiaan. Dengan kata lain merupakan wujud dari kegelisahan sosial intelektual manusia Indonesia yang tidak menginginkan manusia Indonesia tega memakan teman, saudara, rekan, bahkan orang tua sendiri hanya untuk mendapatkan kekayaan dan kesenangan yang bersifat materi. Dengan demikian, pendidikan yang berorientasi kepada human empowering, dialogue oriented dan simpatik minoritas sudah saatnya mendapat tempat bagi semua elemen akademisi. Atau filsafat pendidikan yang membebaskan, kalau tidak, jangan salahkan Paulo Freire yang mengatakan lembaga sekolah adalah candu.Karena itupun beliau mengagagas pendidikan yang membebaskan. Tulisan ini akan membahas filsafat pendidikan yang membebaskan dalam perspektif pendidikan Islam. Uraian ini bersifat deskriptif dan literatur yang digunakan adalah buku-buku pendidikan Islam yang otoritatif, adapun metode yang dipakai adalah metode historis-filosofis.

\section{PARADIGMA FILSAFAT PENDIDIAN PEMBEBASAN DALAM ISLAM}

\footnotetext{
${ }^{1}$ Ainurrofiq, Emoh Sekolah, Yogyakarta, Inspel Ahimakarya Press,
} 2003, h. 43. 
Dalam Alquran, potensi yang dimiliki manusia diistilahkan fitrah atau hati nurani. Potensi tersebut pada esensinya merupakan kemampuan dasar manusia yang meliputi kemampuan rasional, maupun spritual. Hanya saja kemampuan tersebut masih merupakan embrio. Untuk itu, diperlukan upaya untuk mengembangkan dan mengarahkan potensi tersebut secara efektif. Upaya yang efektif adalah melalui media pendidikan. Oleh karena itu, penulis kembali meminjam tesis Muhbib ${ }^{2}$ menyatakan banyak ayat Alquran yang dapat dipahami sebagai ayat pemberdayaan. Diantara indikatornya adalah terjadinya suasana dialogis dalam berbagai kegiatan termasuk pendidikan. Ayat Alquran yang pertama turun kepada Nabi Muhammad Saw adalah perintah baca. Ayat tersebut dapat dinilai sebagai pemicu lahir dan berkembangnya tradisi tulisan, sebagai ganti dari tradisi lisan yang saat itu sangat berkembang. Tradisi tulis menulis merupakan cikal bakal dinamika keilmuan. ${ }^{3}$

Agenda sejarah mencatat bahwa Nabi sudah memulai pendidikan pembebasan. Di mana Nabi mendidik para sahabatnya dari belenggu jahiliyyah, kegelapan spritual dan intelektual yang mencakup sebuah dinamika. Bahkan Nabi memberdayakan para sahabatnya dengan diperintahkan menulis wahyu dan juga tawanan

\footnotetext{
${ }^{2}$ Muhbib melalui tesis Magistenya berkesimpulan bahwa ayat-ayat alQur'an yang berkaitan dengan kisah Nabi Ibrahim mayoritas bergaya bahasa dialogis. Ayat-ayat yang dijumpainya mencapai 237 yang tersebar dalam 25 surat. Jumlah ayat tersebut 83\% nya (197 ayat dalam 13 surat)bergaya bahasa dialogis. Ayat-ayat tersebut mayoritas $(89,85 \%)$ ayat (177 ayat dalam 11 surat) tergolong turun pada priode Mekkah. Tema-tema dialog menyangkut kosmologi, sosial, pendidikan, dan eskatalogi yang merupakan perekat dan penguat ketahuidan. Untuk lebih jelasnya Lihat Muhbib, Konsep Dialog dalam al-Qur'an: Studi tentang kisah Ibrahim AS, Jakarta, Program Pascasarjana, 1997, h. 164. Bahkan surat-surat pendek dalam al-Qur'an juga banyak dijumpai ayat-ayat yang bernuansa dialog, yang diantaranya perhatikan surat, QS. $114: 1,113: 1,112: 1$, 109, 107, 105, 104, 101, 100,: 9, 96, 95:8, 90, 88. Lihat Suwito, Pendidikan Yang Memberdayakan, h. 18.

${ }^{3}$ Suwito, Pendidikan Yang Memberdayakan, h. 18.
} 
perang diperintahkan untuk mengajar membaca dan menulis. Hal ini sangat menarik untuk digarisbawahi bahwa muslim generasi pertama yang hidup sezaman Nabi dan pernah bertemu Nabi, pendidikan Islam memiliki makna sentral sebagai proses pencerdasan secara utuh. Demikain halnya pada masa Khulafa alRasyidin dan setelanya. Hal ini dikemukakan Zarkowi Soejoeti bahwa ketika abad ke $3 \mathrm{H}$, pendidikan Islam tidak lagi meyentuh ilmu keislaman saja, akan tetapi ilmu-ilmu diluar keislaman. Ini dibuktikan dengan dibangunnya Bait al-Hikmah, ${ }^{4}$ sebagai pusat penterjemahan karya-karya warisan ilmu dari Persia dan Yunani. Sehingga revolusi pendidikan abad itu, menghasilkan banyak aktivitas intelektual yang melahirkan banyak aliran pemikir dan mazhab yang terlibat dalam argumentasi dialektika mengenai dasardasar agama (kalam) dan hukum Islam (fikh). Etos kerja ilmiah dan kerja keras tersebut, karena menjadikan Alquran dan As-Sunnah sebagai motivator. Umat Islam sekitar sekitar abad abad 8-9 M, filsafat dan Iptek Yunani tersebut diislamkan, dengan mengganti natural law dengan sunnatullah yakni hukum alam ciptaan Tuhan, dan kebenaran duniawi adalah relatif yang harus terus menerus dikembangkan berdasarkan perspektif kebenaran Tuhan. Dengan demikian, dalam pemahaman nalar metodologi keilmuan yang secara intrinstik menjadi tuntutan universal. Ia didasari, diarahkan, dan dijiwai oleh nilai etik moral Islami, sehingga keduanya akan tetap berkembang dalam perspektif Islam.

Pengembangan filsafat dan Iptek di tangan orang Islam mencapai puncak keemasan pada abad 8-12 M. Pada masa itu pendidikan Islam mampu memimpin kehidupan, di mana manusia

${ }^{4}$ Bayt al-Hikmah Baghdad merupakan salah satu pusat kegiatan penterjemahan ilmu-ilmu dari Yunani ke dalam Bahasa Arab. Pimpinannya adalah Hunayn Ibn Ishaq. Philip K. Hitti, History of Arabs, London, The Macmillan Press, 1974, h. 312. 
berdaya secara maksimal untuk mengendalikan ciptaa-Nya sehingga kehidupan benar-benar nyaman, dan sekaligus maju serta dinamis.

Rahasia kesuksesan pendidikan Islam terletak pada kebebasan mimbar akademik, demokrasi, berpegang teguh pada etika akademik dan estetika. Dalam pandangan Islam antara kebenaran ilmiah, etika, estetika, dan demokrasi merupakan satu kesatuan yang tidak dapat dipisahkan satu sama lainnya, mereka hanya dapat dibedakan menurut posisi dan peran masing-masing. Dalam pandangan Islam, ilmu sudah terkandung secara esensial dalam Alquran. ${ }^{5}$ Karena itu, pada zaman keemasan Islam orang berilmu berarti beragama dan beragama berarti berilmu, maka tidak ada dikotomi antara ilmu umum dan agama. Ilmu tidak bebas nilai, tetapi bebas dinilai atau dikritik. Menilai dan menggugat kembali keabsahan dan kebenaran suatu pendapat adalah suatu keharusan tanpa menilai yang berpendapat. Bahkan ilmuan dengan senang hati melemparkan pendapatnya untuk dinilai dan bukan untuk dipertahankan, karena yang dicari adalah kebenaran dan bukan pembenaran. Dapat dipahami bahwa pendidikan pembebasan dalam perspektif Islam sudah terjadi pada masa Nabi Muhammad dan pada zaman keemasan Islam. Hal ini pun sangat didukung dengan menjadikan Alquran dan Sunnah sebagai motivator pengembangan ilmu pengetahuan. sehingga mampu menghasilkan karya-karya dibidang ilmu pengetahuan. Akan tetapi, kuatnya nilai-nilai kebenaran ilmiah yang dilontarkan oleh para ilmuwan Muslim pada zaman keemasan Islam itu, sampai-sampai pendapat ilmiah tersebut berubah menjadi mitos baru yang hanya perlu dipahami dan dihafalkan serta diamalkan tanpa harus dikritisi.

Pendidikan Islam sesudah abad 12 dirasakan kurang membebaskan terhadap banyak hal. Yang dipelajari ilmu tafsir,

\footnotetext{
${ }^{5}$ Mastuhu, Memberdayakan Sistem Pendidikan Islam, h. 9.
} 
fiqih, dan semacamnya. Bahkan nyaris para peserta didik cenderung dipaksa untuk memahami teks tafsir dan bukannya didorong untuk secara kreatif mengembangkan makna ayat Alquran. ${ }^{6}$ Siswa tidak pernah didorong untuk melahirkan ulum al-Qu'an Baru. Yang ada hanya dipaksa memahami ulum Alquran karya orang lain. Para peserta didik tidak diberi kesempatan untuk melahirkan fiqih baru, yang ada hanya pemikiran fiqih lama. Akibatnya, kitab-kitab selain Alquran cenderung menempati posisi atas dalam pembelajaran dan Alquran ditempatkan pada posisi di bawah atau bahkan tidak sempat dikaji secara mendalam. Dengan demikian, peserta didik kurang memanfaatkan daya pikir yang dimilikinya, sehingga tidak melahirkan manusia yang dinamis akan tetapi fatalistis dan statis. Selain itu, Islam mengalami kemunduran, dengan ditandainya serangkaian peristiwa dramatis baik Baghdad maupun Andalusia. Akibatnya, Islam tidak lagi dapat mengembangkan pendidikan seperti masa-masa sebelumnya yang telah mampu melahirkan sarjana-sarjana terkemuka. Diantaranya seperti al-Biruni, Abu Musa al-Kharizmi dan lain-lain. Hal ini disebabkan karena tidak lagi menjadikan Alquran dan as-Sunnah menjadi motivator penggerak bagi pembebasan atau pemberdayaan. Bahkan Harun Nasution menjelaskan bahwa sesudah abad 13, sejarah peradaban Islam memasuki priode kejumudan, karena orang tidak berani berijtihad. ${ }^{7}$ Selain itu, tradisi pemikiran umat Islam masih belum mampu ke luar dari kungkungan, logosentrisme yang antara lain didominasi oleh: (1) setiap kegiatan berpikir dikuasai oleh gambaran dogmatis dari suatu nalar yang mampu mencapai keberadaan Allah, (2) dorongan utama dari setiap renungan tidaklah bersifat ilmiah tetapi bersifat estetis etis, (3) nalar akal-budi yang merupakan refleksi dari intelegensi adalah ciptaan Allah dan dikuasai oleh gagasan untuk

\footnotetext{
${ }^{6}$ Suwito, Pendidikan Yang Membebaskan, h. 20.

${ }^{7}$ Harun Nasution, "Ijtihad sumber Ketiga Ajaran Islam", dalam Jalaluddin Rakhmat (ed), Ijtihad Dalam Sorotan, Bandung, Mizan, 1988, h. 113.
} 
mengenali kembali pencipta pertama, (4) kegiatan-kegiatan nalar adalah menganjarkan sesuatu dalam usaha kembali ke landasanlandasan dengan bertolak dari definisi-definisi universal, substansisubstansi pertama, dan esensi tidak berubah menurut para pemikir tradisional dan belum tentu menurut makna yang sesungguhnya dari kalam Ilahi. Makna sejati kalam Ilahi tetap tebuka dan tidak berkesudahan untuk terus dicari di diketemukan. Model di atas, tidak pelak lagi mempersempit fungsi dan kemampuan agama dalam merespon tantangan zaman modern dan postmodern, karena dengan model pemikiran tersebut agama terkesan tertutup dan terpisah dari kenyataan keseharian. Karena itu, pendidikan Islam harus mempunyai paradigma baru, yang berdasarkan filsafat teocentris dan sekaligus antroposentris. ${ }^{8}$

Pendidikan Islam terbatas mengajarkan ilmu-ilmu keislaman saja, ${ }^{9}$ yang makin lama makin tidak kreatif sehingga mengalami zaman kemunduran. Di samping itu, di bawah pemerintahan kolonial, umat Islam hanya mempelajari pengetahuan Islam tradisional dan warisan lama, tanpa diperkenalkan pendidikan modern. Akibat berkembangnya dua sistem pendidikan tradisional dan modern di dunia Islam banyak menimbulkan persoalan. Kedua kelompok ini saling mencurigai satu sama lain dan saling menuduh terhadap kelemahan pihak lain, sehingga terputuslah antara ilmu pengetahuan keislaman dengan ilmu pengetahuan modern. Yang pada akhirnya menjadi wacana perdebatan dan kritikan. Bahkan terjadinya penyempitan makna pendidikan Islam berlangsung hingga tingkat pelembagaan dan

\footnotetext{
${ }^{8}$ Mastuhu, Memberdayakan Sistem Pendidikan Islam, h. 15.

${ }^{9}$ Ilmu keislaman yang dipelajari umat Islam seperti ilmu Tafsir, ulumul Qur'an, Fiqhi, dan semacamnya. Ilmu-ilmu tersebut sebenarnya lahir karena adanya al-Qur'an. Akibat dari itu, para siswa dan mahasisiwa cenderung dipaksa untuk memahami teks tafsir dan bukannya didorong untuk secara kreatif mengembangkan makna ayat al-Qur'an.
} 
metodenya, khususnya di kalangan Sunni. Para ulama mulai menarik garis tegas antara ilmu sekuler dan ilmu agama. Mereka menentang ilmu sekuler dan mengeluarkannya dari kurikulum madrasah. Peserta didik lebih banyak diminta menghafal teks baku dibandingkan mengembangkan pemikiran kreatif. Sehingga dalam jangka panjang, akan mengakibatkan disiplin ilmu rasional menjadi tidak berkembang di dunia Islam, yang akhirnya mempengaruhi pemikiran Islam secara keseluruhan pun terhambat karena tidak ada tantangan serta dorongan.

Pendidikan merupakan tuntunan pertumbuhan manusia, sejak lahir sampai tercapai kedewasaan jasmani dan rohani, dalam intraksi dengan alam dan lingkungan masyarakat. Pendidikan merupakan proses yang terus menerus, yang tidak kunjung selasai. Karena itu, proses pendidikan harus menempatkan manusia sebagai titik sentral, namun tidak berarti bahwa pengaruh dan tuntutan masyarakat serta lingkungan sama sekali dilepaskan, maka dalam konteks ini pendidikan berfungsi sebagai wacana intraktif antara manusia dan lingkungan. ${ }^{10}$ Oleh sebab itu, manusia sebagai subyek di dalam pendidikan, maka dituntut tanggung jawab agar tercapai suatu pendidikan yang baik. Dengan demikian, jika manusia sebagai subyek dan pendidikan meletakkan hakikat manusia pada hal yang penting, maka perlu diperhatikan juga masalah otonomi pribadi. Maksudnya adalah, manusia sebagai subyek pendidikan harus bebas untuk "ada" dan menjadi dirinya sendiri, yaitu manusia yang berpribadi dan bertanggung jawab. Ali Syariati salah seorang intelektual Iran yang tersohor, mengatakan bahwa kebebasan yang dimiliki manusia merupakan proses tertinggi dari proses menjadi manusia dengan realitas kemanusiaanya. ${ }^{11}$ Pendidikan pembebasan dalam perspektif Islam sebetulnya telah diterapkan, dan bahkan

\footnotetext{
${ }^{10}$ Malik Fajar, Visi Pembaharuan Pendidikan Islam, h. 63

${ }^{11}$ Malik Fajar, Visi Pembaharuan Pendidikan Islam, h. 64.
} 
bagian dari esensi ajaran Islam sebagai agama yang diturunkan Allah untuk manusia. Mulai Nabi Muhammad dengan gerakan dakwahnya merupakan praktek pembebasan manusia dari eksploitasi, penindasan, dan dominasi dan ketidakadilan dalam segala aspeknya. Karena itu, Nabi dalam misi dakwahnya untuk pembebasan umat, tidak langsung menawarkan Islam sebagai sebuah ideologi yang normatif, melainkan sebagai pengakuan terhadap perlunya memperjuangkan manusia dari tragedi penindasan, ketidakadilan, dengan penyusunan kembali tatanan yang telah ada, menjadi tatanan yang tidak eksploaitatif, adil dan egeliter. Oleh karena itu, Islam dengan pilar lailaha Ilalah adalah agama pemberdayaan dan pembebasan kerena Islam memberikan penghargaan terhadap manusia secara sejajar, mengutamakan kemanusiaan, menjunjung tinggi nilai-nilai demokrasi dan keadilan, mengajarkan berkata benar, dan mengasihi yang lemah dan tertindas. ${ }^{12}$ Sejarah membuktikan bahwa dengn pendidikan pembebasan dalam Islam telah mampu melahirkan masyarakat belajar sehingga banyak karya yang dilahirkan.

Dari cerminan tersebut, maka dapat dipahami bahwa pendidikan Islam telah melaksanakan pendidikan pembebasan, hal ini terlihat tidak adanya dikotomi ilmu pengetahuan, artinya menurut Mulyadhi Kartanegara lahirnya epitimologi Islam yang mampu menpersandinkan antara ilmu yang fisik-empiris maupun non fisik atau metafisika. ${ }^{13}$ Bahkan boleh dinyatakan, bahwa peranan pendidikan saat itu sebagai sarana menyiapkan peserta didik dalam kehidupan masyarakat baik individu maupun sebagai anggota masyarakat. Atau dengan kata lain pendidikan pendidikan telah terjadi pada masa Nabi maupun zaman keemasan Islam.

\footnotetext{
${ }^{12}$ Suwito, Pendidikan Yang Membebaskan, h. 27.

${ }^{13}$ Mulyadhi Kartanegara, Mozaik Khazanah Islam, Jakarta, Paramadina, 2000, h. 117-123.
} 
Pendidikan pembebasan dalam dunia pendidikan Islam pernah dilakukan oleh Nabi dan zaman kejayaan Islam. Hanya saja, pada masa kemuduran menurut Syafi'i Ma'arif, ${ }^{14}$ merupakan kemandulan intelektual kita dalam kurun waktu yang cukup panjang. Akibatnya kita belum mampu merumuskan dan memperkenalkan secara sistematis hal yang baru dalam dunia pendidikan seperti yang digagas oleh Paulo Freire. Ironisnya, kita masih saja berada dalam posisi sebagai umat konsumen terhadap gagasan-gagasan intelektual fihak lain. Kenyataan ini harus kita akui secara jujur. Tapi posisi semacam ini sangat tidak sesuai sama sekali dengan kebesaran dan keagungan Alquran. Posisi subordinat secara intelektual ini, harus secepatnya diubah melalui 'bengkel-bengkel' kerja intelektual yang bernilai strategis untuk memenangkan masa depan. Jalan ke arah itu sebenarnya terbuka lebar itu sebenarnya tebuka lebar bagi intelektual kita. Yang diperlukan sekarang adalah kemauan dan kesungguhan agar masalah cair secara intelektual. Bila kualifikasi ini telah dimiliki, maka khazanah ilmu akan menjadi akrab dengan kita. Tetapi sebaliknya, jika kita masih beku secara intelektual dan wawasan keagamaan masih tetap sempit dan didominasi oleh mitos, golongan, maka jangan heran jika posisi sebagai konsumen masih tetap berlangsung lebih lama. Di sini akan sangat tergantung pada kecerdasan kita dalam menentukan pilihan yaitu sebagai pilihan yang cerdas dan selalu bersifat kritis. Hanya saja sikap kritis dan tidak puas, tidak dipahami sebagai sebuah pemikiran negatif. Sikap kritis seharusnya perlu dikembangkan agar terjadi perkembangan pemikiran dalam bidang ilmu pengetahuan.

Konsep pendidikan sebagai praktek pembebasan yang ditawarkan Paulo Freire, sebenarnya sudah pernah terjadi dalam dunia Islam, kelebihannya barangkali terletak pada kemampuannya

${ }^{14}$ Syafii Maarif, Pendidikan Islam Sebagai Paradigma Pembebasan, Pendidikan Islam di Indonesia; Antara Cita dan Fakta, h. 21. 
untuk merakit gagasan-gagasan kependidikannya dalam suatu teori yang agak baik. Sehingga mampu membawa masyarakat kepada pembebasan dari budaya verbal serba naif dan membosankan bebas dari budaya otoriter yang mendikte dan memerintah, semua ini, merupakan suatu budaya yang mematikan daya kritis dan daya kreatif manusia, menuju masyarakat yang mempunyai kesadaran kritis. Kekurangan dari teori yang dikemas Paulo Freire mengenai konsep atau teori pendidikannya adalah masih terlalu terikat pada kepentingan realitas di muka bumi ini, suatu kepentingan yang belum menyentuh aspek spritual, yang memungkinkan manusia berdialog secara intim dan intens dengan Allah SWT. Karena dengan dialog spritual ini akan memberikan makna yang secara mendasar pada pendidikan khususnya dan bagi kegiatan akademik. Oleh sebab itu, di mata Alquran ekstensi manusia di muka bumi hanyalah bermakna, bila kegiatan di bumi diorientasikan secara sadar ke Allah SWT. Tanpa orientasi semacam itu apapun bentuk kegiatan, termasuk kegiatan pendidikan tidak akan mempunyai nilai disisi-Nya.

Dengan demikian, jika umat Islam ingin mengulang sejarah kesuksesan Islam di masa lalu maka, pertama yang harus ditandinginya adalah membenahi dunia pendidikan Islam. Khususunya pengguruan tinggi, harus mampu menciptakan lingkungan akademik yang kondusif bagi lahirnya praktisi-praktisi yang berpikir kreatif, otentik dan orisinal, seperti pada zaman keemasan Islam. Bukan cendikia-cendekia konsumen yang berwawasan sempit, terbatas dan verbal. Untuk menggiring ke arah itu harus mampu membebaskan civitas akademiknya, dari budaya fanatisme golongan, organisasi dan sebagainya. Serta membawa mereka pada suasana kreatif dalam rangka membentuk kampus Qur'ani, anggun dan menantang secara intelektual. Dengan cara 
tersebut, maka pendidikan dapat menjanjikan sebagai paspor masa depan.

\section{PROBLEMATIKA PENDIDIKAN ISLAM}

Ketika pendidikan Islam menerima sistem dikotomi sebagai sebuah fenomena perbendaan antara sistem pendidikan tradisional dan pendidikan modern, maka menjadi sebuah debat dan beragam kritikan dalam dunia pendidikan Islam yang dilakukan oleh para pembaharu Islam. Abu Hasan al-Amiri (w.381H/992M) misalnya menekankan untuk tidak mengadakan dikotomi pembelajaran ilmuilmu hasil pemikiran dan ilmu-ilmu keagamaan. ${ }^{15}$ Sistem dikotomi pendidikan bukan hanya menyangkut perbedaan dalam struktur luarnya saja tapi juga terjadi di dalam, yang lahir dari pendekatan mereka terhadap tujuan-tujuan pendidikan. ${ }^{16}$ Karena itu, lahirlah konsep keilmuan yang Islami dan tidak Islami, akibatnya, di satu pihak akan menghasilkan manusia yang mempunyai rasa ketaatan yang sangat besar, sedangkan di lain pihak akan melahirkan sosok manusia yang beranggapan bahwa tidak ada batasan atau akhir dari kemungkinan-kemungkinan di dalam dirinya atau dia dapat membentuk sendiri kehidupan yang dijalaninya tanpa tuntunan Ilahi. ${ }^{17}$

${ }^{15}$ Setidaknya ada lima alasan yang dimajukan oleh al-Amiri tentang ini: (1) Wahyu tidak bertentangan dengan pendapat akal, (2) Al-Qur'an mendorong umat Islam untuk mempelajari penciptaan alam, (3) bahwa mempelajari penciptaan alam akan mendapatkan hukum kausalitas, 4) menambah keyakinan, (5) bermanfaat secara nyata bagi kehidupan. Ahamad Abd al-Hamid Ghurab, Abu Hasan al-Amiri wa Ara'uh al-Tarbawiyyah, dalam, Min A'lami al-Tarbiyah alTarbiyyah al-Arabiyyah al-Islamiyyah, Jilid II, h. 96-97.

${ }^{16}$ Syed Sajjad Husain dan Syed Ali Ashraf, Crisis in Muslim Educaion, Jedda King Abdul Aziz Universitas, 1979, h. 56.

${ }^{17}$ Syed Sajjad Husain dan Syed Ali Ashraf, Crisis in Muslim Educaion, h. 56-57. 
Kondisi ini, jelas menjadi sangat dilematis, sehingga disadari atau tidak sebenarnya tugas pemikir muslim juga diarahkan pada upaya sosialisasi konsep pendidikan Islam yang non dikotomik. Problematika pendidikan Islam menurut Mastuhu masih berkutat pada nalar Islami klasik, belum berkutat pada nalar Islami modern. ${ }^{18}$ Sehingga paradigma pendidikan Islam cenderung hanya terkait pada aspek ukhrowinya, ${ }^{19}$ yang menekankan kepada kepatuhan dan tidak berdaya untuk mengkritisi atau dengan paradigma pemikiran kritis. ${ }^{20}$ Oleh karena itu, ilmu-ilmu selain Alquran merupakan hasil Ijtihad, maka perlu dikritisi agar tidak terjebak pada paham bahwa ilmu-ilmu tersebut sebagai ilmu yang telah final dan Absolut.Hal ini dikarenakan para ahli bukanlah manusia ma'shum. ${ }^{21}$

Secara historis melihat problem pendidikan Islam sudah ada ketika sistem madrasah muncul, bahkan madrasah era klasik telah mempunyai peranan yang besar dalam melanggenkan sistem dualisme pada perkembangan pelaksanaan pendidikan Islam selanjutnya, ${ }^{22}$ sehingga sistem pendidikan Islam mengalami ketebelakangan. Namun demikian, pada tataran normatif-filosofis A. Malik Fajar menjelaskan tentang keterbelakangan pendidikan Islam, bahwa hingga kini pendidikan Islam masih berkutat pada perdebatan semantik, apakah pendidikan Islam memakai istilah

\footnotetext{
${ }^{18}$ Mastuhu, "Pendidikan Islam di Indonesia Masih Berkutat pada Nalar Klaisk", dalam Afkar Jurnal Refleksi pemikiran Keagamaan dan Kebudayaan, Edisi, No. 11, 2002, h. 77-83.

${ }^{19}$ Abdurrahmansyah, "Memperbincangkan Sistem Pendidikan Islam", dalam Jurnal Ta'dib, h. 15.

${ }^{20}$ Munir Mulkhan, Islam tidak Hanya Untuk Orang dulu, Ulumul Qur'an, Edisi No3, Vol.VI, 1995, h.11-12.

${ }^{21}$ Ahamad Abd al-Hamid Ghurab, Abu Hasan al-Amiri wa Ara'uh alTarbawiyyah, dalam, Min A'lami al-Tarbiyah al-Tarbiyyah al-Arabiyyah alIslamiyyah, h. 104.

${ }^{22}$ Azyumardi Azra, Pendidikan Islam, Tradisi dan Modernisasi Menuju Milenium Baru, h. ix-xi.
} 
tarbiyah, ta'dib, atau ta'lim. Dari segi muatan, menurutnya pendidikan Islam masih dihadapkan pada persoalan dualismedikotomi antara lain ilmu-ilmu agama dan ilmu-ilmu umum. ${ }^{23}$ Maka, diperlukan reorentasi dan reformasi pendidikan. Lain halnya dengan Fazlur Rahman, berpendapat bahwa keterbelakangan sistem pendidikan Islam adalah karena pengucilannya dari kehidupan intelektualisme. ${ }^{24}$ Atau tertutupnya pintu ijtihad (yakni pemikiran yang orisinal dan bebas) telah membawah pada kemacetan dalam berbagai ilmu pengetahuan.Hal ini diakui Muhammad Iqbal bahwa sistem pendidikan Islam telah digrogoti oleh budaya statisme, sementara dinamisme sangat dihargai oleh Barat. ${ }^{25}$

Selain itu, Nurcholis Madjid menggambarkan kondisi inferioritas pendidikan dunia Islam praktis merupakan kawasan bumi yang paling terbelakang diantara penganut agama-agama besar. Negeri-negeri Islam jauh tertinggal oleh Eropa, Amerika Utara, Australia, dan Selandia baru yang protestan; oleh Eropa Selatan, Amerika Selatan yang Katolik Romawi; oleh Eropa Timur yang Katolik Ortodoks ; oleh Israel yang Yahudi; oleh India yang Hindu; oleh Cina, Korea Selatan, Taiwan, Hongkong dan Thailand yang Buhdis. Praktis tidak satupun agama besar di muka ini yang lebih rendah kemajuan ilmu pengetahuan dan teknologinya (Iptek) daripada Islam. ${ }^{26}$

${ }^{23}$ A.Malik Fajar, Reorientasi Pendidikan Islam, h. 79.

${ }^{24}$ Muhaimin, Kontroversi Pemikiran Fazlur Rahman, Studi kritis Pembaharuan Pendidikan Islam, Cirebon, Pustaka Dinamika, 1999, h. 75.

${ }^{25}$ Ahmad Syafii Maarif, Imron Nasri (Ed), Islam dan Politik Upaya Membingkai Peradaban, Cirebon, Pustaka Dinamika, 1999, h. 143. Baca pula, The Recontruction of Religions Thought in Islam, New Delhi, Kitab Bhavan, 1981, h. 146.

${ }^{26}$ Nurcholis Madjid, Kaki Langit Peradaban Islam, Jakarta, Yayasan Wakaf Paramadina, 1997, h. 21 
Secara internal ada dua hal yang menyebabkan ketertinggalan kaum muslimin seperti yang digambarkan di atas yakni: Pertama, karena pola pikir muslim yang secara umum sangat kental bercorak fikih oriented, yang selanjutnya bersikap apriori terhadap semua aktivitas penalaran, rasionalistik.Kedua, kurangnya sosialisasi konsep filsafat pendidikan Islam.fenomena inferioritas ini setidaknya merupakan konsekwensi logis dari obyektivitas mental kaum muslimin yang dalam konteks sejarah diakui telah meninggalkan tradisi ilmiah radikal yang untuk kemudian larut secara sempurna ke dalam dimensi sufistik dan meninggalkan eksplorasi empirik.

Untuk itu, suatu alasan dasar untuk kemudian bermunculan ide-ide islamisasi sebagai kritik terhadap ideologi muatan nilai ilmu dan sosial, ${ }^{27}$ secara tegas al-Faruqi mengatakan bahwa umat Islam harus menjadi umat yang cerdas dengan menata paradigma pendidikannya yang modern, namun tetap berpijak pada asas moralitas Islami yang paling dasar. ${ }^{28}$

Apa yang dilakukan Ismail al-Faruqi tentang Islamisasi ilmu merupakan sebuah fenomena yang tidak bisa dielakkan. Ketika membicarakan arti nilai, dalam konteks filosofis, nampaknya kita sangat setuju jika persoalan ini menjadi hal yang dianggap penting oleh peradaban masa depan. Bahkan menyayangkan bahwa penampilan budaya global dan modern cenderung mengabaikan nuansa nilai, sehingga Barat telah berhasil mengalihkan pengetahuan tentang mesin-mesin dan teknologi.Tetapi tidak sukses

${ }^{27}$ Muhammad Yasien, Islamisasi Ilmu Pengetahuan; Studi Perbandingan Faruqi dan Rahman, dalam Jurnal Media, Edisi 22, Tahun IV Juli, Semarang, h. 17.

${ }^{28}$ Ismail Raji Al-Faruqi, Islamisasi Ilmu Pengetahuan, terj. Bandung, Pustaka, 1995, h.xii-xiii. 
mengalihkan warisan-warisan moral kebudayaan dan spritual pada generasi. $^{29}$

Pendidikan Islam dalam konstalasi percaturan masa depan dengan melihat kecederungan dan sekaligus ancaman sebagaimana yang dideskripsikan di atas, sepertinya diharapkan mampu mengkombinasikan wacana modern dan tradisional dalam bentuk paradigma pendidikan yang dapat memformulasikan kepetingan manusia (humanisasi) dan kebutuhan akan kesejukan Ilahi (teologis). Dengan kata lain konsep pendidikan Islam tidak hanya melihat bahwa pendidikan itu sebagai upaya mencerdaskan (intelek, kecerdasan), melainkan sejalan dengan konsep Islam tentang manusia dan hakekat ekstensinya. Dalam pemikiran pendidikan Islam, eksetensi manusia dilihat secara integral dan harmonis. Kesatuan dimensi potensi yang dimiliki manusia, merupakan kekuatan yang ampuh dalam mengantarkan manusia menjadi makhluk yang mulia dan mampu melaksanakan amanat Allah SWT, secara optimal yang nantinya akan dipertanggung jawabkan di hadapan-Nya. Untuk itu, posisi dan fungsi pendidikan adalah untuk menstimulir agar semua potensi yang dimiliki peserta didik dapat berkembang secara terpadu semaksimal mungkin, serta mengarahkan agar perkembangan potensi tersebut, senantiasa selaras dengan nilai religius Tuhan. Untuk mengembangkan konsep ini, pendidikan yang dilaksanakan harus mampu menjalin kerja sama yang harmonis dan integral dengan berbagai pihak yang terkait, baik secara struktural politik maupun struktur sosial, dalam satu visi dan misi. Kesemua unsur dan dimensi yang ada harus senantiasa berjalan beriringan dan saling melengkapi antara satu dengan yang lain. Kondisi ideal ini, menjadikan pendidikan yang ditawarkan akan lebih menggigit dan lahan kondusif bagi

${ }^{29}$ H. Harold Titus (ed), Persoalan-Persoalan Filsafat, terj. Jakarta, Bulan Bintang, 1984, h. 130. 
pengembangan manusia seutuhnya. Sebaliknya, jika pendidikan Islam tidak mampu menjalin kerja sama yang harmonis dan integral, maka ia berfungsi sekedar menara gading di tengah derap globalisasi yang cepat, tidak mustahil pada gilirannya akan tergilas dan akhirnya secara perlahan-lahan mati di telan perubahan. ${ }^{30}$

Pemikiran yang ditawarkan bersifat dinamis, fleksibel, universal dan mengandung nila-nilai pembebasan manusia dari atmosfir berfikir teoritis yang kaku dan sakral. Harmonisasi antara pendekatan filosofis dan agama, merupakan langkah yang strategis dalam membantu mengantarkan peserta didik agar mampu mambangun sebuah tatanan peradaban yang lebih baik. Melalui pendekatan ini, pemikiran pendidikan Islam akan dapat menemukan arah yang lebih sesuai dan memiliki daya hidup, terutama dalam menentukan kebijaksanaan pendidikan yang universalsitik. ${ }^{31}$ Hasim Amir menjelaskan bahwa pendidikan Islam adalah pendidikan yang idealistik yakni integralistik, humanistik, pragmatik dan berakar budaya yang kuat, ${ }^{32}$ sehingga pendidikan Islam mampu

\footnotetext{
${ }^{30}$ H.M. Irsjad Djuwaeli, Pembaharuan Pendidikan Islam, h. 77.

${ }^{31}$ Samsul Nizar, Pengantar Dasar-Dasar Pemikiran Pendidikan Islam, h. 211 .

${ }^{32}$ Intergralistik mengandung komponen-komponen kehidupan yang meliputi, Tuhan, manusia, dan alam pada umumnya sebagai suatu yang integral bagi terwujudnya kehidupan yang baik, serta pendidikan yang manusia sebagai sebuah pribadi jasmani-rohani, intelektual, perasaan dan individu sosial. Pendidikan yang humanistik dapat diharapkan mengembalikan hati manusia ditempatnya yang semula, dengan mengembalikan manusia kepada fitrahnya, dengan berfikir, bekemauan dan bertindak sesuai dengan nilai-nilai luhur kemanusiaan yang bisa mengganti sifat individualistik, egoistik, dengan sifat kasih sayang kepada sesama manusia, sifat ingin mencari kesamaan dan lain sebagainya. Sedang pendidikan pragmatik pendidikan yang dapat diharapkan dapat mencetak manusia pragmatik yang sadar akan kebutuhan kebutuhan hidupnya, terhadap masalah-masalah kemanusiaan dan dapat membedakan manusia dari kondisi dan situasi yang tidak manusiawi. Serta pendidikan yang berakar budaya yang kuat akan dapat diharapkan membentuk manusia kepribadian, harga diri, percaya pada diri sendiri, dan membangun peradaban berdasarkan budayanya sendiri yang merupakan warisan monumental dari
} 
menyiapkan kader-kader khalifah, sehingga secara fungsional keberadaanya menjadi pemeran utama terwujudnya tatanan dunia yang rahmatan lil-'alamin. Namun, dalam lintasan sejarah yang panjang, disadari atau tidak, sebagai warisan dari sistem pendidikan priode klasik adalah persoalan sekarang sangat terkait dengan sistem pendidikan yang ditawarkan. Di satu sisi, sistem pendidikan hari ini masih terkesan dikotomi. Sedangkan di sisi lain, oreientasi pendidikan masih mengacu pada aspek verbalistik dengan titik tekan pada visi hafalan, bukan pengembangan makna dasar, serta perluasan wawasan intelektual dan moral. Akibatnya, seluruh sistem yang ada di dalamnya terimbas kepada kedangkalan makna dan kemudian kegagalan dalam misinya. Ahmad Syafii Maarif mengatakannya bahwa out put pendidikan Islam tak mampu memiliki komitmen spritual dan intelektualisme yang kokoh terhadap nilai esensi ajaran Islam. ${ }^{33}$ Sistem pendidikan Islam yang diperlukan saat ini adalah rekonstruksi pendidikan Islam sebagai sebuah paradigma pembebasan, yaitu pendidikan yang mampu menempatkan peserta didik pada posisi sentral dalam setiap perubahan yang terjadi, serta mampu pula mengarahkan dan mengendalikan setiap perubahan itu. Dengan demikian usaha pembaharuan pendidikan Islam muncul sebagai reaksi bahwa pendidikan Islam tidak mampu menyesuaikan dengan kondisi perkembangan masyarakat, hal ini sebagai konsekuensi logis dari perkembangan masyarakat untuk menyesuaikan diri dengan kemajuan ilmu pengetahuan dan teknologi. Pembaharuan pendidikan Islam dapat dilihat dari berbagai aspek, salah satu aspeknya adalah aspek konsepsional. Untuk mengatasi problematika pendidikan Islam saat ini. Hal ini dapat dilihat agenda pendidikan

warisan masa lalu. Akan tetapi bukan orang yang anti kemodernan, yang menolak begitu saja arus transformasi budaya dari luar.

${ }^{33}$ Ahmad Syafi'i Ma'arif, Peta Bumi Inteletualisme Islam di Indonesia, Bandung, Mizan, 1993, h. 146. 
|RAUSYan FiKR, Vol. 13 No.2Desember 2017:287-320

Islam yang dikemukakan Irsyad Djuawaeli, menurutnya ${ }^{34}$ pendidikan Islam harus mempunyai paradigma pembelajaran bersifat penguatan dialogis.

Penguatan paradigma dialogis artinya dalam menghadapi era globalisasi seperti sekarang ini pendidikan Islam sering mendapat sorotan tajam dari para praktisi pendidikan. Sorotan itu antara lain mengenai rendahnya mutu pendidikan yang dihubungkan dengan kebutuhan akan sumberdaya manusia (SDM) yang berkualitas tinggi. Karena itu, dalam konteks kebutuhan pembaharuan pendidikan sebagai proses penyempurnaan terus dilakukan. Usaha ini berkaitan dengan fenomena meningkatnya jumlah murid/siswa, makin tinggi tingkat kompetisi pendidikan, meningkatnya pengangguran terdidik, dan berbagai persoalan lainnya yang berkaitan dengan kondisi pendidikan. Jika pada tataran kebijakan, konsep dan pendekatan pendidikan mengalami penyempurnaan, proses pembelajaran pun mengalami perubahan. Sebab kegiatan pendidikan merupakan perjumpaan (interaksi) dan komunikasi timbal balik yang terarah pada pengembangan gagasan, kreativitas, sikap nilai, serta keterampilan, maka proses pembelajaran tidak bisa disederhanakan sekedar kegiatan mendengarkan ceramah. Tetapi proses belajar mengacu kepada bagaimana cara belajar yang memungkinkan siswa berpikir, bersikap dan bertindak menurut ajaran Islam. Artinya dengan interaksi dan komunikasi belajar adalah perjumpaan partisipatif antara guru dengan murid yang ditunjukkan kepada pengembangan gagasan, pikiran, suasana harmonis dan demokratis. Dikatakan perjumpaan partisipatif, karena intraksi dan komunikasi belajar mengajar berlangsung dua arah, sehingga terjadi proses saling mempengaruhi antara subyek belajar (guru dan murid). 144-145.

${ }^{34}$ H. M. Irsyad Djuwaeli, Pembaruan Kembali Pendidikan Islam, h. 
Belajar adalah kegiatan yang terorganisasi dan terintegrasi di mana seluruh komponen pendidikan terpusat pada rencana belajar, yakni mengembangkan kreativitas berpikir, bertindak dan berketerampilan. Karena itu, makin kuat hubungan guru dengan murid dalam proses belajar mengajar, makin dinamis dan kondusif suasana pembelajaran, sehingga menumbuhkan kegairahan bagi murid dan guru dalam mengikuti proses belajar mengajar. Untuk itu, rencana kegiatan pembelajaran harus sistematis, terarah kepada tujuan berdasarkan tahapan-tahapannya, serta out put yang ingin dicapai harus jelas dan terukur berdasarkan waktu yang tersedia. Dalam perencanaan itu pula guru harus menempatkan murid sebagai subyek yang melakukan tindakan ke arah pengembangan berpikir, bertindak dan berkarya nyata. Melalui pembelajaran dialogis akan lahirlah kesadaran kritis pada diri anak didik, sehingga mereka mampu menanggapi, menilai, membentuk dan mempengaruhi jalannya prose pembelajaran. Dengan demikian kondisi belajar mengajar akan hidup yang gilirannya turut pula memperkuat sikap kepekaan mereka terhadap segala bentuk perkembangan pendidikan dan lingkungan sosialnya. Demikian pula pengalaman hidup akan beragama akan berkembang dinamis dengan memperkaya khazanah intelektual dan kesadaran moralitas pada diri anak didik. Tokoh pendidikan Islam al-Taumi menuliskan bahwa "pendidikan Islam menekankan pentingnya pengetahuan tentang hubungan dan pertalian paralel di antara unsur-unsur pengalaman pengajaran yang satu dengan lainnya". ${ }^{35}$ Hubungan pertalian pembelajaran itu berlaku bagi kegiatan murid dalam membentangkan sayap pengalaman kognitif dan psikomotoriknya antara pengalaman yang lama dengan pengalaman yang baru sehingga terjadi kontiunitas. Al-Taumy lebih lanjut mengatakan "pengalaman pembelajaran tersebut merupakan pendahuluan untuk 143.

${ }^{35}$ H. M. Irsyad Djuwaeli, Pembaruan Kembali Pendidikan Islam, h. 
menolong peserta didik dalam memperoleh pengalaman masa depan. Dengan begitu akan terbentuk sifat-sifat yang berkelanjutan proses keberlanjutan proses belajar mengajar". ${ }^{36}$ Agenda pembaharuan pendidikan Islam harus dapat mengembangkan kemampuan belajar untuk lebih lanjut mengembangkan kemampuan metodologi ilmiah. Karena itu, kepada anak didik harus dikembangkan pemikiran kreatif dan liberal agar mampu membuat pilihan tepat dan akurat serta memgembangkan metode rasional, empris, bottom up dan menjadi. ${ }^{37}$

Pendidikan Islam harus mampu mencari paradigma baru, salah satu adalah pendidik harus bebas dari masalah komitmen, profesinalisme, serta penghasilan. Dengan kata lain, mereka harus mempunyai komitmen tinggi, dan merasakan pendidikan sebagai panggilan tugas. Kemudian profesionalisme lengkap dengan kepekaan misi dan ketajaman visi serta kecanggihan metodologi, dan guru dan ilmuan perlu memiliki penhasilan cukup agar benarbenar memiliki tanggalan 30 hari dalam sebulan. Seiring dengan kemajuan ilmu pengetahuan dan teknologi, kebutuhan manusia akan informasi juga makin tinggi. Maka profesionalisme guru merupakan hal yang berarti dalam dunia pendidikan. Kerena itu, makin tinggi kualitas guru, memungkinkan mutu dan produk (out put) pendidikan juga tinggi, sehingga mendorong kegairahan pengembangan belajar lebih lanjut bagi anak didik. Tetapi guru yang tidak berkualitas memungkinkan mutu sekolah rendah yang berakibat rendah pula minat dan prestasi belajar siswa. Hal ini pun sangat ditentukan oleh profesionalisme guru, artinya profesionalisme sebuah bidang pekerjaan yang dalam pandangan sebagai suatu pengabdian melalui keahlian tertentu dan menganggap keahlian ini sebagai sesuatu yang 143.

${ }^{36}$ H. M. Irsyad Djuwaeli, Pembaruan Kembali Pendidikan Islam, h.

${ }^{37}$ Mastuhu, Memberdayakan Sistem Pendidikan Islam, h. 16 
harus secara terus menerus diperbaharui dengan memanfaatkan kemajuan-kemanjuan yang terdapat dalam ilmu pengetahuan. Di samping itu, dalam pembelajaran dialogis perlu ditumbuhkan cinta terhadap sesama, artinya intreaksi dan komunikasi belajar mengajar harus dibangun di atas fondasi cinta kasih terhadap sesama manusia. Cinta kasih adalah sifat kepada Tuhan (ar-Rahman dan ar-Rahim) yang juga diberikan pada manusia, sebagai makhluk theomorfis, harus mampu mewujudkan sifat tersebut dalam berbagai aktivitas kehidupan. Melalui pendidikan sifat-sifat luhur itu harus dipelihara, dikembangkan dan diaktualisasikan dalam bentuk yang konkrit. Melalui sikap cinta kasih ini belajar mengajar akan menumbuhkan keberanian untuk mengembangkan bakat, minat dan seluruh kemampuan dirinya. Namun sebaliknya, belajar tanpa didasari oleh sifat tersebut akan menumbuhkan rasa takut bagi peserta didik. Karena rasa cinta merupakan sebuah keberanian, bukan ketakutan, maka orang akan merasa iba pada dirinya dan orang lain, sehingga akan membentuk tindakan pengembangan diri melalui belajar, berfikir dan bertindak. Konsep ini dalam dunia pendidikan memainkan peran penting untuk mendobrak sekat-sekat kehidupan yang membelenggu semangat kemanusiaan. Cinta kasih merupakan potensi untuk memperkuat kebersamaan integritas hidup dalam keberagamaan dan perekat kebersatuan dan keterpaduan. Atas dasar itu, maka kegiatan pembelajaran akan dapat berlangsung secara dialogis, antara guru dengan murid. Tanpa rasa cinta terhadap sesamanya, mustahil kegiatan pembelajaran yang komunikatif dan dialogis itu dapat mewujudkan dalam dunia pendidikan.

Agenda pembaharuan pendidikan Islam yang lain adalah kurikulum, merupakan salah satu komponen inti pendidikan, yang kedudukannya tidak seperti kitab fiqh yang sulit dirubah. Pertimbangan masa depan menjadi tuntutan yang harus ada dalam kurikulum. Karena setiap kurikulum dipersiapkan hanya untuk masa 
tertentu dan tempat tertentu, maka aspek elastisitas, integritas dan efektifitas menjadi sangat penting untuk dituangkan ke dalam isi kurikulum. Karena itu, kurikulum tidak boleh didasarkan pada skenario kehidupan masa kini saja. Robert Zais menyebutnya kurikulum "shaping the individual salves, i, e determening what men become". ${ }^{38}$ Untuk mencapai hal tersebut, kurikulum berfungsi untuk membentuk peserta didik agar menjadi orang, artinya kurikulum berfungsi untuk membentuk peserta didik agar menjadi seseorang yang diinginkan. Untuk itu, kurikulum harus berorientasi kepada masa depan (future oriented), sesuai dengan keadaan kondisi dan situasinya. ${ }^{39}$ Karena kurikulum yang berorientasi pada masa depan akan cenderung dapat mengembangkan kreativitas peserta didik sebagai karunia Tuhan yang sangat berharga. Tetapi kurikulum yang berorientasi kepada masa lalu, cenderung menciptakan image diri eksklusif dan anti perubahan. ${ }^{40}$ Aspek lain yang perlu diusahakan adalah membentuk keterkaitan integratif antara isi kurikulum dengan tuntutan perkembangan masyarakat. Dalam konteks ini kegiatan pembelajaran senantiasa terkait dengan kehidupan nyata masyarakat, sehingga sekolah berfungsi sebagai wahana bagi perubahan sosial. Aspek ini sangat penting mendapat perhatian dari pengelolah dan pengembangan kurikulum, sehingga out put pendidikan dapat menjawab kebutuhan masyarakat. ${ }^{41}$ Dengan melihat pemikiran pendidikan Islam di atas,

\footnotetext{
${ }^{38}$ S. Robert Zais, Curriculum: Principles and Foundations, New York, Harper Z Publishers, 1976, h. 201.

${ }^{39}$ Moh. Ansyar, 'Kurikulum Dalam Menyongsong Otonomi Pendidikan Di Era Globalisasi, Peluang, Tantangan, dan Arah', dalam Jurnal Ta'adib, No. 4, Maret 2001, h. 99-110. 155.

${ }^{40}$ H. M. Irsyad Djuwaeli, Pembaruan Kembali Pendidikan Islam, h.

${ }^{41}$ Untuk lebih jelasnya dalam Ornestein dan Hunkins yang dikutip Moh. Ansyar, yang mengajukan enam komponen yang dikembangkan kurikulum masa beroirentasi masa depan : (1) memiliki akses ke informasi, (2) mampu berpifikir kritis, (3) mampu berkomunikasi efektif, (4) memahamimi lingkungan manusia,
} 
baik dari aspek pembelajaran, guru yang profesional maupun pembaharuan kurikulum, pendidikan Islam hendaknya mampu membebaskan seluruh komponen dunia pendidikan baik peserta didik dan pendidik, kurikulum, maupun masyarakat untuk mencapai tujuan pendidikan. Bahkan lebih luas lagi dikatakan H. Syaukani HR, bahwa untuk menemukan titik temu dalam dunia pendidikan seluruh komponen bangsa, yakni pemerintah, pendidik, masyarakat, dan orang tua dalam tanggung jawab pendidikan, bekerja sama menjadi sarana dan media pembelajaran untuk memberikan iklim kondusif tercapainya masyarakat pembelajar.

\section{REFORMULASI FILSAFAT PENDIDIKAN ISLAM; PARADIGMA PEMBEBASAN}

Sistem pendidikan Islam yang ada secara umum terkesan lamban dan kurang produktif dalam membangun sosok pribadi peserta didik yang berkualitas paripurna. Di lain pihak, dinamika yang ditampilkan pendidikan saat ini telah keropos dari nilai-nilai sakral Ilahiah. Demikian pula sebaliknya pendidikan Islam hanya mampu melahirkan sosok manusia terdidik secara afeksi. Pelaksanaan pendidikan Islam dalam kaitan moralitas dan sikap individual jujur harus dipahami sebagai kesuksesan besar yang tidak perlu diragukan. Akan tetapi jika dihadapkan dengan diskursus kajian modern sistem pendidikan Islam terkesan lesu darah.

Prediksi di atas, nampak merupakan persoalan yang menggejala dan telah merambah hampir seluruh dimensi kehidupan manusia, dan tidak bisa dipungkiri bahwa selama ini pendidikan Islam hanya melahirkan sosok peserta didik cenderung bersifat

(5) memahami individu dan masyarakat, (6) meningkatkan kompetensi berikut: pengetahuan, berpendidikan, bertanggunjawab, peduli pada kesejahteraan sosial. Baca Moh. Ansyar, 'Kurikulum dalam Menyongsong Otonomi Pendidikan di Era Globalisasi, Peluang, Tantangan, dan Arah', dalam Jurnal Ta'adib, h. 108. 
dikotomi-parsial. Untuk keluar dari persoalan konsep pendidikan yang dikembangkan seharusnya menjadi pemikiran dan perlu upaya kreatif analitik, untuk mengembangkan rekayasa progresif dalam menata kehidupan di muka bumi ini. Untuk itu, perlu mereformasi pendidikan Islam dari waktu ke waktu tanpa henti. Kita tidak boleh lagi selalu membanggakan keberhasilan pendidikan pada masa lampau (bukan melupakan sejarah) tanpa mengkaji ulang relevansi keberhasilan itu dengan setting global masa kini dan masa yang akan datang. ${ }^{42}$

Usaha pembaharuan dan peningkatan kualitas pendidikan Islam menurut Azyumardi Azra sering bersifat sepotong-potong atau tidak komprehensif dan menyeluruh dan terkesan tambal sulam sehingga sebagian besar sistem pendidikan Islam, belum dikelola secara profesional. ${ }^{43}$ Bahkan bahwa sistem pendidikan Islam seharusnya senantiasa mengorientasikan diri bagaimana menjawab kebutuhan dan tantangan yang muncul dalam masyarakat sebagai konsekuensi logis dari perubahan. Oleh karena itu, menurut Fazlur Rahman, wacana pendidikan Islam masa depan setidaknya ada tiga hal yang harus diredifinisikan. Pertama, tujuan pendidikan Islam yang bersifat defensif dan cenderung berorientasi pada kehidupan akhirat harus segera dirubah. Kedua, beban psikologi umat Islam dalam menghadapi Barat harus dihilangkan. Ketiga, sikap negatif kaum muslimin terhadap pengetahuan Barat semestinya dibuang. ${ }^{44}$

Selanjutnya dalam rangka menemukan jati diri dalam menyongsong masa depan lembaga pendidikan Islam harus

\footnotetext{
${ }^{42}$ Suyanto dan Djihad Hisyam, Refleksi dan Reformasi Pendidikan di Indonesia Memasuli Milenium III, Yogyakarta, Adicita Karya Nusa, 2000, h. 2.

${ }^{43}$ Azyumardi Azra, Pendidikan Islam, Tradisi dan Modernisasi Menuju Milenium Baru, h. 59.

${ }^{44}$ Muhaimin, Kontroversi Pemikiran Fazlur Rahman, Studi Kritis Pembaharuan Pendidikan Islam, h.105-106.
} 
menumbuh kembangkan sikap seperti; memahami orientasi, memilah-milah yang terbenar dan terbaik, kemampuan mengelolah dan mengendalikan, kemempuan mengembangkan pelajaran, dan kemampuan berijtihad. ${ }^{45}$

Berkaitan dengan itu, Muhammad Iqbal menggambarkan bahwa lembaga pendidikan Islam harus mampu melahir peserta didik mard-e mo'min sebagai tipe manusia ideal yang mempunyai oreintasi spritual, tetapi yang kedua kakinya berpijak di dunia kenyataan. Mard-e mo'min adalah manusia yang punya kapasitas tangguh untuk mengarahkan jalan sejarah. Ekstensi mard-e mo'min baru punya makna bila mampu membebaskan dirinya dari statisme dan ketergantungan. ${ }^{46}$ Ia mengatakan kualiatas utama yang harus dimiliki oleh mard-e mo'min keluaran lembaga-lembaga pendidikan Islam harus memiliki dua kualitas; Pertama, kemampuan untuk melestarikan dan memelihara kehidupan. Inilah yang diistilahkan dalam bahasa Persi dengan hefz-e zendgi.Kedua, adalah taqwim e $k h u d i$, yaitu kemampuan untuk menyatakan dan menegaskan diri dalam kehidupan ini dengan kepala tegak. ${ }^{47}$ Dari alur pemikiran

\footnotetext{
${ }^{45}$ Mastuhu, Memberdayakan Sistem Pendidikan Islam, h. 48-49.

${ }^{46}$ Ahmad Syafii Maarif, Imron Nasri (Ed), Islam dan Politik Upaya Membingkai Peradaban, 143.

${ }^{47}$ Ungkapan dua kualitas di atas dilukiskan dalam asrar-e khudi sebagai berikut :

mendapatkan informasi

Tantangan Pengetahuan dan ilmu

Bukan satu-satunya tujuan.

Kuncup dan kembang

Tidak Mungkin

Menggantikan padang rumput

Pengetahuan haruslah menjadi alat

Untuk memelihara kehidupan

Pengetahuan haruslah menjadi alat

Untuk menyatakan dan menegaskan diri.

Ungkapan taqwim-e khudi adalah semakna dengan ungkapan isbe-e khudi (penegasan diri). Ini lawan dari doktrin nafi-e khudi (peniadaan diri), suatu
} 
Iqbal di atas, dapat dipahami bahwa pendidikan Islam seharusnya mampu melahirkan sosok peserta didik mard-e mo'min yang akan membebaskan diri dari sikap defensip intelektual, sehingga dapat berlaku opensif dengan menampilkan karya-karya bermutu tinggi, orisinal dan sejati.

Pelaksanaan pendidikan Islam selama ini, dalam tataran pragmatis sesungguhnya mengalami gap yang cukup besar jika dikaitkan dengan nilai-nilai dasar kefilsafatan pendidikan Islam. Hanya saja dalam dimensi ontologis dan sistemnya, pemikir muslim harus mengalami perubahan mendasar, sebab Islam memandang empiris dan rasio sebagai bagian integral dan eksistensi Ilahi, sehingga tujuan atau aksiologi ilmu tidak bisa dilepaskan dari kehendak-Nya. ${ }^{48}$ Dalam rangka menjembatani gap dari kekeliruan merumuskan konsep pendidikan, al-Faruqi melalui visinya, menentukan paling tidak ada lima agenda mendasar yang disebutnya dengan rencana kerja Islamisasi pengetahuan yang harus dicermati dalam menata paradigma pendidikan. Pertama, penguasaan disiplin ilmu modern. Kedua, penguasaan khazanah Islami. Ketiga, penentuan relevansi Islam bagi masing-masing bidang modern. Keempat, pengarahan aliran pemikiran Islam ke jalan yang mencapai pemenuhan pola rencana Allah. ${ }^{49}$ Apa yang dilakukan al-Faruqi merupakan sebuah upaya menuju model pendidikan terpadu, dimana pembinaan keimanan dan pengetahuan harus bersanding.

kualitas yang diagung-agungkan oleh sebagian sufi. Akibat dari doktrin nafi-e khudi ini menyebabkan jatuhnya citra Islam di tangan umatnya. Baca Ahmad Syafii Maarif, Imron Nasri (Ed), Islam dan Politik Upaya Membingkai Peradaban, h. 144.

${ }^{48}$ Chabib Thoha (Peny), Reformulasi Filsafat Pendidikan Islam,h. 49.

${ }^{49}$ Ismail Raji Al-Faruqi, Islamisasi ilmu Pengetahuan, h. 98. 
Di sisi lain yang perlu diberdayakan dalam pendidikan Islam merupakan sarana pemberdayaan individu dan masyarakat guna menghadapi masa depan. wacana lama praktek pendidikan Islam yang memposisikan siswa sebagai objek yang terkesan pasif adalah salah satu bentuk penginkaran dari konsep murid dalam diskursus pendidikan Islam. Oleh sebab itu, guru memiliki tanggung jawab terhadap perkembangan anak didik dengan mengupayakan perkembangan seluruh potensi termasuk afeksi, kongnisi dan psikomoriknya, ${ }^{50}$ dengan tanggung jawab seperti ini, maka tugas seorang guru bukan lagi knowledge based, seperti yang sekarang dilakukan, tetapi lebih bersifat menekankan pada penguasaan secara optimal konsep keilmuan dan perekayasaan yang berdasarkan nilai-nilai etika dan moral. Konsekwensinya, seorang guru tidak lagi menggunakan satu arah yang selama ini dilakukan, melainkan menciptakan suasana kelas yang kondusif sehingga terjadi komunikasi dua arah secara demokratis antara guru dengan murid. ${ }^{51}$ Kondisi seperti ini diharapkan dapat menggali potensi kreativitas anak didik.

Dari sisi peserta didik, yang harus dilahirkan dari pendidikan Islam yakni mempunyai paradigma yang kokoh secara spritual, unggul secara intelektual, dan anggung secara moral dengan Alquran sebagai acuan yang pertama dan utama. ${ }^{52}$ Peserta didik harus diberi pelajaran Alquran melalui metode yang memungkinkan anak untuk menjadikan Alquran sebagai rujukan dalam segala tindakannya. Untuk itu, ada dua tahap yang harus dilakukan yaitu; memahami makna dari pernyataan Alquran dengan mengkaji situasi dan problem historisnya, dan selanjutnya

\footnotetext{
${ }^{50}$ Ahmad Tafsir, Ilmu Pendidikan dalam Perspektif Islam, h.74-75.

${ }^{51}$ Indra Djati Sidi, Menuju Masyarakat Belajar; Menggagas Paradigma Baru Pendidikan, h. 39.

${ }^{52}$ Ahmad Syafi'i Ma'arif, Imron Nasri (Ed), Islam dan Politik Upaya Membingkai Peradaban, h. 121-122.
} 
mengeneralisasikan jawaban spesifik Alquran dan menyatakan sebagai pernyataan-pernyataan yang memiliki tujuan moral dan sosial, umum yang dapat disaring dari ayat dengan latar belakang sosial historis. ${ }^{53}$

Sistem pendidikan yang tawarkan dapat harus dapat melepaskan peserta didik dari bentuk kungkungan dalam berbagai bentuk. Sebagai pendidikan pembebasan, pendidikan Islam tidak dapat melepaskan diri dari ketiga domain pendidikan yakni kognitif, afektif dan psikomotorik. ${ }^{54}$ Di samping itu, yang perlu diberdayakan dalam pendidikan Islam adalah penegasan hirarki nilai dan merumuskan kembali konsep-konsep ilmu-ilmu sosial dan alam serta kemanusiaan. ${ }^{55}$ Kerangka pandang umat Islam tidak perlu lagi terjadi pemisahan antara ilmu agama dengan ilmu umum, tetapi wawasan integratif yang memandang ilmu sebagai satu kesatuan utuh dalam memahami realitas dan rahasia Tuhan adalah opini utama yang harus disosialisasikan kepada kalangan muslim. Dengan demikian, produk pendidikan Islam sebagai paradigma pembebas seyogiyanya mampu menciptakan peserta didik mempunyai daya kritis, dan mempunyai akhlak, menumbuhkan nuansa spritual yang akhirnya mampu mengatisipasi masa depan umat Islam menuju kepada universalisme dan pluralisme. Dengan cara demikian, reformulasi pendidikan Islam tidak akan terserabut dari akar sejarah kegemilangan pendidikan Islam yang sangat konsisten dan kuat memegang prinsip-prinsip moralitas dalam mengkontruksikan peradaban. Untuk itu, kemampuan metodologis dan rekayasa empiris merupakan salah satu instrumen yang harus

\footnotetext{
${ }^{53}$ Fazlur Rahman, Islam and Modernty; Tranformation of an Intelektual Tradition, Chicago, University of Chicago Press, 1984, h. 6.

${ }^{54}$ M. Rusli Karim, Pendidikan Islam di Indonesia Antara Cita dan Fakta, h. 39 .

${ }^{55}$ Syed Ali Ashraf, Horison Pendidikan Islam, h. 19.
} 
dikuasai, dan pada akhirnya pendidikan Islam harus mampu membebaskan peserta didik.

\section{PENUTUP}

Berdasarkan pembahasan dari awal sampai akhir, maka penulis dapat menyimpulkan bahwa filsafat pendidikan yang membebaskan dalam perspektif Islam pernah terjadi dalam dunia pendidikan Islam yakni pada zaman Rasulullah SAW sampai pada zaman keemasan Islam. Namun demikian, setelah kemunduran dunia Islam sampai sekarang praktis virus dikotomi telah terjadi, bahkan filsafat pendidikan pembebasan tidak lagi terjadi dalam dunia pendidikan Islam. Oleh karena itu, pendidikan Islam seharusnya mampu menjadi sarana pembebasan untuk menyiapkan peserta didik untuk terjun dalam kehidupan masyarakat. Di samping itu, dikotomi ilmu sudah seharusnya ditiadakan dengan memandang bahwa ilmu itu satu semuanya berasal dari Islam. Filsafat pendidikan yang membebaskan akan terwujud jika pendidikan Islam mau melakukan reorientasi:

a. Memiliki visi, misi, dan orientasi strategis ke depan yang jelas.

b. Memiliki legistimasi sosial, intelektual dan moral yang kuat.

c. Bebasis pada masyarakat dan meresponi tuntutan zaman

d. Dikelola dengan menajemen modern yang profesoinal, rasional, terbuka, akuntabel, humanis, memiliki akses, kerjasama dan kemitraan global.

\section{DAFTAR PUSTAKA}


Abd al-Hamid Ghurab Ahmad, Abu Hasan al-Amiri wa Ara'uh alTarbawiyyah, dalam, Min A'lami al-Tarbiyah al-Tarbiyyah al-Arabiyyah al-Islamiyyah, Jilid II.

Ahmad Syafii Maarif, dan Imron Nasri (Ed), Islam dan Politik Upaya Membingkai Peradaban, Cirebon, Pustaka Dinamika, 1999.

Ainurrofiq, Emoh Sekolah, Yogyakarta, Inspel Ahimakarya Press, 2003.

Al-Faruqi, Ismail Raji, Islamisasi Ilmu Pengetahuan, terj. Bandung, Pustaka, 1995.

Ansyar, Moh. 'Kurikulum Dalam Menyongsong Otonomi Pendidikan Di Era Globalisasi, Peluang, Tantangan, dan Arah', dalam Jurnal Ta'adib, No. 4, Maret 2001.

Ashraf,Syed Ali Horison Pendidikan Islam, h. 19.

Azra,Azyumardi, Pendidikan Islam, Tradisi dan Modernisasi Menuju Milenium Baru, Jakarta, Logos, 2000.

Chabib, Thoha (Peny), Reformulasi Filsafat Pendidikan Islam, Yogyakarta, Pustaka Pelajar, 1996.

Djati Sidi, Indra, Menuju Masyarakat Belajar, Menggagas Paradigma Baru Pendidikan, Jakarta, Paramadina dan Logos Wacana Ilmu, 2001.

Djuwaeli,H.M. Irsjad, Pembaharuan Pendidikan Islam, Jakarta, 2000

Fajar, A.Malik, Reorientasi Pendidikan Islam, Jakarta, LP3NI, 1998 ,

Fazlur Rahman, Islam and Modernty; Tranformation of an Intelektual Tradition, Chicago, University of Chicago Press, 1984.

Kartanegara, Mulyadhi Mozaik Khazanah Islam, Jakarta, Paramadina, 2000. 
Samsul Bahri,Filsafat Pendidikan yang Membebaskan ...

Ma'arif, Syafi'i Ahmad, Peta Bumi Inteletualisme Islam di Indonesia, Bandung, Mizan, 1993.

Maarif,Syafii, Pendidikan Islam Sebagai Paradigma Pembebasan, Pendidikan Islam di .Indonesia; Antara Cita dan Fakta, Tiara Wacana, 1991.

Madjid, Nurcholis, Kaki-Kaki Langit Peradaban Islam, Jakarta, Yayasan Wakaf Paramadina, 1997.

Fajar Malik, Visi Pembaharuan Pendidikan Islam,Jakarta, LP3NI, 1998 ,

Mastuhu, "Pendidikan Islam di Indonesia Masih Berkutat pada Nalar Klaisk", dalam Afkar Jurnal Refleksi pemikiran Keagamaan dan Kebudayaan, Edisi, No. 11, 2002.

Mastuhu, Memberdayakan Sistem Pendidikan Islam, Jakarta, Logos, 1999.

Muhaimin, Kontroversi Pemikiran Fazlur Rahman, Studi kritis Pembaharuan Pendidikan Islam, Cirebon, Pustaka Dinamika, 1999.

Muhbib, Konsep Dialog dalam Alquran: Studi tentang kisah Ibrahim AS, Jakarta, Program Pascasarjana, 1997.

Mulkhan, Munir, Islam tidak Hanya Untuk Orang dulu, Ulumul Qur'an, Edisi No3, Vol.VI, 1995.

Nasution, Harun, "Ijtihad sumber Ketiga Ajaran Islam", dalam Jalaluddin Rakhmat (ed), Ijtihad Dalam Sorotan, Bandung, Mizan, 1988.

Nizar, Samsul, Pengantar Dasar-Dasar Pemikiran Pendidikan Islam, Jakarta, Gaya Media Pratama, 2001.

Philip K. Hitti, History of Arabs, London, The Macmillan Press, 1974.

Suwito dalam upacara pengukuhan sebagai guru besar pada tanggal 3 Januari 2002 yang berjudul Pendidikan yang Memberdayakan. 
320 |Rausyan FiKR, Vol. 13 No.2Desember 2017:287-320

Suyanto dan Djihad Hisyam, Refleksi dan Reformasi Pendidikan di Indonesia Memasuli Milenium III, Yogyakarta, Adicita Karya Nusa, 2000.

Syed Sajjad Husain dan Syed Ali Ashraf, Crisis in Muslim Educaion, Jedda King Abdul Aziz Universitas, 1979.

Tafsir,Ahmad, Ilmu Pendidikan dalam Perspektif Islam,Bandung, Remaja Rosdakarya, 2001.

Titus, H. Harold (ed), Persoalan-Persoalan Filsafat, terj. Jakarta, Bulan Bintang, 1984.

Yasien, Muhammad, Islamisasi Ilmu Pengetahuan; Studi Perbandingan Faruqi dan Rahman, dalam Jurnal Media, Edisi 22, Tahun IV Juli, Semarang, 2002.

Zais,S. Robert, Curriculum: Principles and Foundations, New York, Harper Z Publishers, 1976. 